\title{
Two indigenous European crayfish under threat - how can we retain them in aquatic ecosystems for the future?
}

\author{
S. Peay ${ }^{(1)}$, L. Füreder ${ }^{(2)}$ \\ Received June 8, 2011 \\ Accepted July 11, 2011
}

\section{ABSTRACT}

Key-words: Indigenous crayfish species (ICS) are under threat in Europe; due to comAustropotamobius, petition from invasive non-indigenous crayfish species (NICS) from craycrayfish, conservation, management, biological invasion fish plague, which is carried by introduced American crayfish, and habitat degradation. We focus on the white-clawed crayfish Austropotamobius pallipes and stone crayfish $A$. torrentium. Surveys in many countries have shown the accelerating rate of loss since the late 20th century; concurrent with rapid spread of NICS by human-assisted introductions and natural expansion. Remaining populations of ICS are becoming fragmented. As NICS become ever more extensive, it will become progressively harder to retain populations of European ICS.

Legal protection alone is not sufficient against the major threats from NICS and crayfish plague. We recommend catchment-scale risk assessments, to identify threats and to guide action plans: (1) populations of ICS where loss is inevitable, (2) those at some risk that can be made more secure by various measures and (3) existing or new isolated populations that can be kept secure, "ark sites". Resources can be targeted to achieve specific conservation goals. Ark sites are likely to offer the best chance for survival of both Austropotamobius species, where there are invading NICS. We discuss constraints and opportunities and the need for public involvement.

\section{RÉSUMÉ}

Deux écrevisses indigènes européennes en danger - Comment peut-on les conserver dans les écosystèmes aquatiques à l'avenir?

Mots-clés : Les espèces d'écrevisses indigènes (ICS) sont menacées en Europe à cause de Austropotamobius, la compétition par les espèces d'écrevisses non indigènes et invasives (NICS), et écrevisse, conservation, gestion, invasion biologique de ce fait par la peste des écrevisses portée par les écrevisses américaines introduites et enfin à cause de la dégradation de l'habitat. Nous traiterons du cas de l'écrevisse à pattes blanches Austropotamobius pallipes et de l'écrevisse des torrents $A$. torrentium. Les inventaires menés dans plusieurs pays ont montré la perte accélérée de leurs populations depuis le $20^{\mathrm{e}}$ siècle et ceci de façon concomitante avec la rapide invasion des NICS introduites par l'homme et selon leur progression naturelle. Les populations subsistantes des ICS sont devenues fragmentées. Comme les NICS deviennent de plus en plus répandues, il deviendra de plus en plus difficile de préserver les populations d'écrevisses indigènes (ICS) en Europe.

(1) University of Leeds, Institute of Integrative and Comparative Biology, Leeds, LS2 9JT, UK, stephanie@crayfish.org.uk

(2) River Ecology and Invertebrate Biology, Institute of Ecology, University of Innsbruck, Technikerstrasse 25, 6020-Innsbruck, Austria, Leopold.Fuereder@uibk.ac.at 
La protection légale n'est pas suffisante à elle seule pour lutter contre les menaces majeures telles que la présence des NICS et leur peste. Nous recommandons d'évaluer les risques à l'échelle du bassin hydrographique, pour identifier les menaces et élaborer des plans d'action selon 3 cas : (1) les populations des ICS dont la perte est inévitable, (2) celles menacées mais que l'on peut sauvegarder par différentes mesures et (3) les populations existantes ou nouvellement isolées qui peuvent être conservées dans des «sites sanctuaires ». Des ressources peuvent être ciblées pour établir des plans spécifiques de conservation. Les sites sanctuaires semblent offrir la meilleure chance pour la survie des espèces du genre Austropotamobius par rapport à la progression des NICS. Nous discutons des contraintes et des possibilités ainsi que la nécessité d'impliquer le public.

\section{INTRODUCTION}

Overall, European indigenous species of crayfish (ICS) are now in decline and there are growing concerns that unless there is concerted action to conserve the European ICS they will be progressively replaced by invasive non-indigenous crayfish species (NICS) in most or all of their range.

The introduction of highly invasive, non-indigenous species is one of the major threats to biodiversity globally, leading to the reduction and loss of indigenous species, as they are replaced by invasive species or whole new assemblages of non-indigenous species (Millennium Ecosystem Assessment, 2005). Freshwater aquatic ecosystems and the biological communities within them can be radically altered by human-assisted introductions of some nonindigenous species of fish and invertebrates. Among the successful aquatic invasive species there have been several of the North American species of freshwater crayfish, which were introduced into Europe, mainly in the late 20th century, although some European species have also been introduced beyond their natural range in Europe. The impacts of NICS have been reviewed by various authors, including Holdich (1999), Gherardi (2007), Füreder and Pöckl, (2007), Holdich and Pöckl, (2007) Holdich et al. (2009) and Reynolds (this volume). Impacts of NICS on European ICS arise from (1) the role of North American NICS as vectors of the disease crayfish plague (Aphanomyces astaci), which causes mass mortality in populations of European crayfish; (2) changes in aquatic communities, including alteration of habitat by burrowing and damage to aquatic vegetation, and (3) competition, if the NICS are not carrying or expressing crayfish plague. ICS in Europe are all decreasing in their range in watercourses and in still water sites, as shown in the compiled data in the European Atlas (Souty-Grosset et al., 2006) and the recent supplement by Holdich et al. (2009).

The white-clawed crayfish Austropotamobius pallipes has a range extending from countries bordering the eastern Adriatic Sea, through southern and central Europe as far as Spain and northwest to the British Isles. Molecular genetic studies of $A$. pallipes have led to recognition of separate subspecies, but here it is considered as a species complex, as in Grandjean et al. (2006). A. pallipes has suffered major losses, more than $70 \%$ since the 1970 s in parts of its range in England, France and Italy (Holdich et al., 2009). Recognition of high rates of loss of $A$. pallipes in the past decade led to its listing as Endangered in the IUCN Red List of Threatened Species (Füreder et al., 2010a). The stone crayfish Austropotamobius torrentium has a more restricted distribution in central Europe including Greece, and has little overlap with A. pallipes. It is also described as a species complex (Schubart and Huber, 2006). Austropotamobius torrentium is also declining in range, but the available information on the rate of loss in the past decade was not sufficient for classification under the IUCN criteria on loss, so the classification assigned in the IUCN Red List was Data Deficient (Füreder et al., 2010b), although this species is also likely to be Endangered. This is especially the case in several Alpine countries or regions, e.g. Austria (Füreder et al., 2009a), Carinthia (Weinländer and Füreder, 2009), Switzerland (Hefti and Stucki, 2006), and Eastern Europe (Maguire, 2009). 
By contrast, the NICS are established and increasing their ranges. Cases by country are summarized in (Holdich, 2002; Souty-Grosset et al., 2006; Holdich et al., 2009). There are at least eight NICS from North America and two from Australia established in Europe already. There are differences between countries as to which of the NICS is most prevalent or spreading fastest, but the pattern of human introduction of NICS is similar, with establishment, invasion and subsequent impact on ICS and other receptors. Currently, the most prevalent NICS in Europe are signal crayfish Pacifastacus leniusculus, spiny-cheek crayfish Orconectes limosus and red swamp crayfish Procambarus clarkii, with the first two being the earliest species introduced. Of these, $P$. leniusculus is capable of occupying all habitats occupied by European ICS and has wider environmental tolerance. It is already widely distributed across Europe from the Iberian peninsula northeast across central Europe to the Baltic Sea and as far north as central Finland. Orconectes limosus prefers slower-flowing rivers and lakes and may not extend as far up catchments as $P$. leniusculus, but it is already the predominant crayfish in France, is widespread across Europe as far as Lithuania (Souty-Grosset et al., 2006) and is spreading rapidly through the Danube catchment (Puky and Schád, 2006). Whilst $P$. clarkii is mainly in low-lying areas in the Mediterranean countries, populations occur as far north as the Netherlands and south-east England.

All of the established NICS are considered to be a threat to ICS and were rated as being of high or medium invasiveness when species risk assessments were carried out (Peay et al., 2010; Tricarico et al., 2010). The spread of NICS is by a combination of natural expansion and by human-assisted introductions, both deliberate and accidental.

NICS and crayfish plague are the dominant threats in many areas and are sure to become increasingly so, due to ongoing expansion of the range of NICS in catchments across Europe and the associated spread of disease. Whilst several strains of crayfish plague have been identified (Söderhäll and Cerenius, 1999), all of them are lethal to European ICS. In addition to these two major threats, other anthropogenic influences have led to losses of range of European ICS, especially the two Austropotamobius species, due to reduction of the quality of habitat. This has caused loss of range or reduced natural abundance of indigenous crayfish populations, even in areas not currently colonized by NICS.

Impacts on Austropotamobius have arisen from changes in landuse in the 20th and 21st centuries across Europe and the associated reductions in the quality of habitat for crayfish (e.g. Füreder et al., 2003, 2006). Adverse impacts occur due to organic pollution (Foster and Turner, 1993; Lyons and Kelly-Quinn, 2003; Trouilhé et al., 2003, 2007); pollution from pesticides, especially synthetic pyrethroids (Howells and Slater, 2004) siltation from intensification of agriculture and erosion from access routes or commercial forestry (Lerat et al., 2006; Garcia-Arberas et al., 2010) Drought, or climatic conditions in combination with abstraction of water, has also been identified as a contributing factor in the decline of some populations of Austropotamobius, where drying of sections of streams has caused fragmentation and isolation of populations (Martinéz et al., 2003; Renai et al., 2006). Where channels have been modified for land drainage, populations of Austropotamobius have been lost during the works and may have been unable to re-colonize the limited habitats, although in England $A$. pallipes has successfully colonized some artificial watercourses, notably parts of the canal network (Peay, 2003). As slow-growing species, any recovery of populations of Austropotamobius species from short-term impacts can take several years. Over-harvesting has been suggested as a possible reason for decline of $A$. pallipes in some regions (Thomas and Ingle, 1971; Renai et al., 2006), although in practice it may be difficult to differentiate this from other impacts.

Yet, despite this suite of major problems threatening the survival of both Austropotamobius species, or rather because of them, there is increasing interest in the conservation of $A$. pallipes and $A$. torrentium. There is a growing body of research and conservation projects, as shown, for example by six issues of this journal on freshwater crayfish ( $>140$ papers, mainly European studies), between 2002 and 2010. In this paper we use examples of recent work on the conservation of two European species: $A$. pallipes in England and A. torrentium in Austria 
to highlight the similarities in the approach conservation strategy and actions, the problems encountered and the scope to retain both species within the European aquatic fauna.

We consider that the threats to both $A$. pallipes and $A$. torrentium are such that action is needed urgently, even though there may be some uncertainties about long-term outcomes and there will always be incomplete information on the distribution of ICS and NICS. We recommend a structured approach towards developing action plans for the conservation of Austropotamobius species. We are of the view that whilst legislation and regulation are necessary at a range of scales: European, national and regional (regions as administrative areas within countries here), it is at the scale of catchments and sub-catchments that conservation action plans for Austropotamobius species need to operate, although, as we discuss below, some catchments within Europe are transnational. We make several recommendations to further conservation of Austropotamobius species in their European range: (1) put regulation in place; (2) plan and coordinate action; (3) assess risk at catchment scale; (4) prepare and implement conservation action plans; (5) involve people with the conservation of crayfish. The recommendations are discussed below.

\section{RECOMMENDATIONS ON CONSERVATION STRATEGY FOR INDIGENOUS CRAYFISH}

\section{> PUT REGULATION IN PLACE}

Legislation and regulations cannot prevent further losses of Austropotamobius species on their own, but we consider that they are important to the conservation of Austropotamobius species. Legislation for crayfish has been introduced in many countries in Europe in the past 20 years, to protect populations and habitats of ICS, to regulate import, keeping or sale of NICS; the stocking of NICS and harvesting. Within the European Union (EU), both the Austropotamobius species are listed under the EU Habitats Directive (92/43/EEC), under Annex II, which requires Special Areas for Conservation to be set up to conserve the species. Austropotamobius torrentium is listed as a priority species, giving it the highest level of protection throughout its range in the EU member states. Both Austropotamobius species have status as protected species, but there is considerable variation in regulation of the exploitation of crayfish, especially NICS, in different European countries. There are differences between countries and even between regions within countries with respect to crayfish farming, harvesting and stocking, use as angling bait and sale of NICS for aquaria. Concerns have been expressed by many authors about the limitations of this regulation (Vigneux et al., 2002; Souty-Grosset et al., 2004; Edsman and Smietana, 2004; Holdich and Pöckl, 2005; Reynolds et al., 2006; Holdich et al., 2009; Peay, 2009a). Issues raised include the different responsibilities of organizations, lack of consistency and coordination, differing objectives and priorities and conflicts between conservation and commercial exploitation of crayfish.

Edsman and Smietana (2004) noted the potential for sustainable harvest of European ICS in some cases, which may be feasible with some populations of noble crayfish Astacus astacus and narrow-clawed crayfish Astacus leptodactylus, but is less likely to be feasible or appropriate for the two Austropotamobius species. Edsman and Smietana (2004) acknowledged, however, that harvesting of NICS increases the likelihood of further introductions, as has been the case in Sweden (Edsman, 2004) and Spain (Alonso et al., 2000). Even where there is legislation for the conservation of ICS and management of NICS, there are problems of enforcement in many countries in Europe (Peay, 2009a).

Legislation to give Austropotamobius species formal protection does not necessarily deal with the threats of NICS and crayfish plague, for which separate regulations may be required. A range of pathways for introductions of crayfish have been identified (Peay et al., 2010), all of which are human-assisted. Aquaculture, which starting in the mid 1970s, was the initial source of many populations of NICS that invaded streams and rivers in England and Wales. Other deliberate and accidental releases have occurred; from angling and related activity, including 
use of angling bait and with stocking of fish for angling; introductions for wild harvesting of crayfish; discards of crayfish from aquaria, and release of surplus live crayfish intended for human consumption. The same pathways have also been routes for introductions of NICs within the geographic range of Austropotamobius in mainland Europe.

Regulation can be used to block, or at least minimize, the pathways by which introductions of NICS occur. For example, efforts have been made in the UK to make the protection of $A$. pallipes more effective by improving regulation of human activity with NICS. Austropotamobius pallipes was given legal protection from taking and sale in the UK from 1985, but specific regulation to try to prevent further releases of NICS did not start until after 1992, and a ban on use of crayfish as angling bait only came into force from 2005.

There has been a growing interest in wild harvesting of signal crayfish in England, fuelled by media attention on the plight of white-clawed crayfish and promotion of signal crayfish as a fashionable wild food. Since 2007, trapping of any crayfish species in England has required an annual consent for specific locations. The number of applications to trap $P$. leniusculus in England increased annually, to 845 by 2010 (Environment Agency, 2010), most of which were for small-scale trapping for personal consumption, rather than commercial harvesting and were mainly in the south-east of England. There is growing pressure on the regulatory agencies to allow trapping of $P$. leniusculus in geographic areas where it is not allowed at present. Incidences of crayfish trapping without consent are reported to the Environment Agency periodically, but it is difficult to estimate how much wild harvesting goes on in areas where it is not allowed and the risks from the illegal activity.

In England and Wales the time taken to put regulation in place meant that it was more difficult for regulation to be effective than it would have been if there had been early action. There is a risk that areas of Europe that are not yet dealing with major invasion of catchment by NICS may be similarly complacent before the onset of problems, unless there are strong pressures for regulation. The Water Framework Directive (2000/60/EC) requires member states of the European Union to assess waterbodies for good ecological status. The presence of extensive populations of certain invasive non-indigenous species, including signal crayfish, is sufficient to down-grade rivers below the threshold for good ecological status (or good ecological potential, the term used where waterbodies are highly modified). Already some 43 riverine water bodies (out of 5,818 in England and Wales) are likely to fail to achieve "good ecological status" because of signal crayfish (Hansard, 2011). This is likely to be an under-estimate, because there is little monitoring of the spread of NICS populations after they are first detected. Furthermore, with $P$. leniusculus already present in most catchments in England and Wales and a high likelihood that there are recent populations that are unrecorded to date, the number of waterbodies which are non-compliant due to NICS is certain to increase in future.

Legislation operates mainly at national scale, but there are variations in the way associated regulations are applied in regions within countries, especially where government is decentralized, as in a federal system. Nonetheless, the main scale at which action is required if the two Austropotamobius species are to be conserved in future is at the scale of individual catchments and sub-catchments.

In our view, legislation needed at national scale for all European countries with either of the Austropotamobius species is as follows:

- legal protection for indigenous crayfish species;

- no introductions of non-indigenous crayfish permitted;

- no keeping of non-indigenous crayfish in aquaria, or else no import or keeping of any species assessed to have a risk of establishment or impact;

- no export of live crayfish, or else no export to areas where import or keeping is not allowed.

In addition, we recommend that in catchments with populations of either of the Austropotamobius species the risks to the ICS can be minimized by introducing regulations on fisheries management; we consider there should be:

- no sale or use of crayfish as angling bait;

- regulation of any wild harvesting of crayfish to provide safe-guards for indigenous crayfish, especially measures to prevent spread of crayfish plague; 
- regulation of fish-stocking, or a code of practice, to minimize the risk of introduction of non-indigenous crayfish or crayfish plague.

\section{> PLAN AND CO-ORDINATE ACTION FOR CRAYFISH CONSERVATION}

There is a need to coordinate policy and conservation strategy at a range of scales. National agencies with statutory responsibilities relating to the water environment, or those with responsibilities for regions or federal states within countries, are the most likely to take a lead in developing and implementing policy on freshwater crayfish. These regulators may take a lead in developing national strategy, in order to fulfill one or more of their statutory responsibilities, but it is likely to be most effective if done in conjunction with other stakeholders.

In England, for example, the stakeholders involved in activities that are relevant to crayfish conservation can be grouped into four main categories. These are the regulators, conservation groups, anglers and landowners. The regulators include the government environmental agencies, local planning authorities and the navigation authority that owns and manages most of the canals. The conservation groups are mainly charitable trusts and other community organizations working at national or local levels, notably the wildlife trusts and the rivers trusts. The category 'anglers' includes angling clubs and the bodies representing the interests of anglers, also crayfish trappers and fish farms. Recreational anglers have been a major lobby group for the protection and improvement of the aquatic environment in England, but some of their activities may have risks for ICS too, notably the risk of transmission of crayfish plague. Some other recreational users of waterbodies may also pose some risks of transmitting crayfish plague. Landowners include a wide spectrum of private and public sector owners whose land management can have positive or negative effects on habitat quality for freshwater crayfish. It includes the water utility companies, which have reservoirs with dams in many catchments.

A species action plan was developed for $A$. pallipes as part of the UK Biodiversity Action Plan (UK Biodiversity Steering Group, 1995). Some progress has been made on most of the original aims, including more regulation on NICS, but within the regions in England and Wales progress has been much more variable, with action to conserve populations of $A$. pallipes tending to be localized within relatively small administrative areas or individual sites. In an effort to improve coordination and target action more effectively, the Environment Agency (a government regulatory body in England and Wales) prepared a biodiversity strategy for $A$. pallipes in England (Christmas, 2009) and this has been followed by guidance on planning actions to conserve the indigenous crayfish at catchment scale (Peay et al., 2011).

From the early 1990s, in England and Wales, local Biodiversity Action Plans for particular habitats and species were mostly at the scale of administrative counties or smaller metropolitan districts and few were specifically for $A$. pallipes. Administrative boundaries do not usually coincide with catchment boundaries; consequently, there is a need to coordinate between administrative areas in action for freshwater crayfish. The same is so for other protected species in watercourses. There are ten River Basin Districts (Water Framework Directive catchment areas) covering England and Wales, but they coincide only approximately with the administrative regions or counties. This means there are often multiple agencies and many other stakeholders potentially involved in catchments and even more of them at the scale of River Basin Districts.

Within the ranges of $A$. pallipes and $A$. torrentium in mainland Europe most of the river basin districts are international. There are some national ones in Spain and in most of Italy and the Loire in France, but elsewhere the Austropotamobius populations occur within international river basin districts. This means there is potential for transboundary impacts of NICS and crayfish plague, as well as the impacts of impoundment or diversion of watercourses and pollution from a range of sources. Even within individual countries the range of stakeholders potentially involved means there is scope for uncertainty about remits and responsibilities, especially if planning and action have financial implications. There is potential for duplication, omissions or conflicting policies, any of which may hamper efforts towards conservation of 
ICS. Different regulations applied by various regional governments within Spain and at national scale led to inconsistencies and continued losses of $A$. pallipes populations (Alonso et al., 2000) and similar problems have been reported within some other European countries from conflicts or inconsistencies between legal protection of ICS and fisheries or harvesting regulations (Peay, 2009a). Setting up national strategy and catchment action plans will make it easier to identify worthwhile conservation action; direct funds into effective implementation of conservation action for Austropotamobius species, and identify any research which is needed to inform and support conservation action.

For catchments within one country, we suggest the best approach is for a regulator or conservation group to act as lead partner, with a coordinating role, monitoring progress of the action plan and encouraging other stakeholders to be involved in planning and implementing actions. Other key stakeholders are fishing interests and landowners, because they generally have a significant influence on what happens to populations of indigenous crayfish in individual catchments. Unless those groups are consulted and any conflicts are addressed, it will be difficult to achieve conservation targets in practice. A good example of a coordinated stakeholder group for crayfish conservation in England is the South-West Crayfish Conservation Group. This involves a group of partners, principally the Environment Agency, the Avon Wildlife Trust (a charitable conservation organization) and Bristol Zoo (Nightingale, 2009). The positive experience in the South-West of England is encouraging action in other regions of England, most importantly those in northern England, where there are the most extensive remaining populations of $A$. pallipes. Groups in the regions are now developing their own action plans and taking on new projects, for example in Cumbria, South Yorkshire, Derbyshire, Nottinghamshire and Norfolk.

For catchments in two or more countries, conservation action plans can be made in each, but there needs to be co-operation between the participants in the different countries at least on the issues with potential for trans-boundary effects. Co-ordination of conservation strategy will be critically important on control of NICS and in some cases on issues of water quality, water usage, or modification of watercourses, any of which may be relevant to the conservation of ICS in one or more of the countries in the catchment. The case study of the Austrian and Italian Tyrol outlined in this paper is one of the few examples so far of trans-boundary co-operation on crayfish conservation. The cross-border cooperation between Northern Ireland (part of the United Kingdom) and the Republic of Ireland on crayfish conservation and prevention of non-native species is another example (Reynolds, 2009).

\section{>ASSESS RISK AT CATCHMENT SCALE}

We consider that a catchment risk assessment for crayfish is an essential early stage in any local action plan for Austropotamobius species, to assess any current or potential threats to the populations. There are similar threats to the species across their range, but there are differences in the magnitude of impact of specific threats, the likely time-scale and the potential for mitigating the effects.

The starting point for a catchment risk assessment is the distribution of indigenous and nonindigenous crayfish species within a geographic area. The coverage and reliability of distribution data depends on having resources available to carry out surveys and a biological recording system to check and compile records. Records may be from a range of sources, such as detailed surveys for crayfish, incidental records from aquatic biological monitoring for other species or habitats, or ad hoc records from members of the public.

Distribution data are unlikely to be comprehensive or entirely current. The success of invasions of NICS in Europe means that past records for NICS tend to remain current; survey records are likely to be under-estimates of the extent of populations at the time, and populations may have expanded range since the last record. By contrast, where populations of A. pallipes or $A$. torrentium are under threat, positive records may be out of date rapidly, due to local reduction or loss of populations. This adds an element of uncertainty into risk assessments at catchment scale, especially the threat from NICS, which may be worse than 
assumed, or conversely, because there may be unidentified relict populations of ICS that are in need of protection or conservation measures to aid recovery.

Because the geographic coverage of historic records may vary considerably, it may be useful to estimate the extent of current and historic populations of ICS or NICS and hence rates of change. Lack of interpreted distribution data was a constraint in assessing the rate of loss of range of the Austropotamobius species in the past ten years, the IUCN criterion which led to classification of $A$. pallipes as Endangered, during the recent IUCN Red List review. Extent of the species populations is also likely to be needed for assessment of the status of Austropotamobius species under the EU habitat regulations, especially where GIS mapping provides a useful tool for landscape-scale analysis Following a catchment risk assessment, extent of population(s) may be one of the measures used to assess success of a conservation action plan.

Field records of crayfish distribution and geographic information can be used to assess relationships between crayfish, habitat suitability and land-use factors (e.g. Schulz et al., 2002; Martinéz et al., 2003; Hefti and Stucki, 2006). Use of habitat suitability indices can show differences between areas potentially suitable for Austropotamobius species and the current extent of populations. In some cases, a loss of range can be inferred from this, even if there are few actual historical records. Assessing the quality of habitats is a component of risk assessments at the landscape level. For example, the analysis of catchment properties and habitat characteristics in 125 freshwater habitats in the Italian province of South Tyrol (predominantly streams and rivers, since few South Tyrolean crayfish populations occur in standing waters) showed that existing locations with $A$. pallipes had predominantly moderate to poor catchment and habitat conditions (Füreder et al., 2003). In freshwaters where there were historical crayfish records but populations are now extinct, catchment and habitat conditions were even worse. Locations lacking evidence of crayfish occurrence had somewhat better habitat conditions, perhaps because proportionally more intact than impaired waters were inspected for potential crayfish sites. These sites are now being considered for crayfish action plans.

Proximity to NICS is the major risk factor to assess in a catchment risk assessment because it dominates decisions about management action. Due to overlap of ecological niches there is no habitat suitable for Austropotamobius species where they cannot be out-competed by one or more of the NICS. Where NICS are established and expanding in a catchment that is wholly or partly occupied by an Austropotamobius species the survival time for the indigenous crayfish depends on: the rate of invasion in upstream and downstream directions; the number and nature of physical barriers to invasion; the likelihood of human-assisted introductions extending the invasion, and whether the population of NICS is carrying crayfish plague. If the population of $A$. pallipes or $A$. torrentium is continuous along a watercourse and relatively abundant the first outbreak of infection of crayfish plague can trigger rapid loss of the whole population, whereas if the population is discontinuous, due to barriers or localized adverse factors, this may be sufficient to prevent complete loss.

Although populations of $A$. pallipes or $A$. torrentium may be found in catchments that are still entirely free from NICS, there is always a risk that one or more populations of a nonindigenous crayfish species is already present, but not yet detected. The more human settlements, angling activity and other recreational access there are, the greater the risk of introductions of NICS. Increasingly, Austropotamobius populations occur in the headwater streams of catchments where NICS have already been confirmed in the lower reaches or other tributaries. A catchment risk assessment should consider whether invading populations of NICS are likely to reach existing populations of Austropotamobius in each catchment or sub-catchment. Whether the indigenous crayfish can survive in the long term depends on the barriers separating their populations from NICS. This is essential for conservation in situ, re-stocking populations lost due to crayfish plague or pollution (Kemp et al., 2003), or starting new, isolated ark sites to conserve populations of indigenous crayfish (Peay, 2009b). 


\section{> PREPARE AND IMPLEMENT CONSERVATION STRATEGY AND ACTION PLAN AT REGION AND CATCHMENT SCALE}

Having assessed the distribution of the crayfish and the threats to Austropotamobius species, there is a need for conservation action plans that will avoid or minimize the threats to populations and prioritize action and resources to get the best outcomes. An example of this is in the Tyrol in the Alps of central Europe, which consists of the Austrian federal state of Tyrol (North Tyrol and East Tyrol), and the Italian province of SouthTyrol. These are areas subject to their respective national laws, but with local powers. About ten years ago management activities were started (a) to summarize distribution and threats to the endangered populations of freshwater crayfish in the Austrian and Italian Tyrol (b) to give a general outline of the proposed and partly implemented species action plans, and (c) to demonstrate how water management activities combined with crayfish research can be used for crayfish protection. Due to the mountainous topography of both provinces, freshwater crayfish generally occur at lower elevations in lakes and rivers of the larger valleys, where temperature regime and channel stability enable the successful survival of crayfish populations.

Füreder et al. (2002) concluded that there had been a major decrease in the number of crayfish waters, given that in South Tyrol about 50 locations were recorded in the literature. The comparison with former distribution studies in South Tyrol showed that even within the previous two to three decades, the crayfish situation became worse, and new data re-emphasizes the ongoing trend. The same study showed that in South Tyrol the records for non-indigenous crayfish $A$. astacus and $O$. limosus had increased whereas, $A$. pallipes populations either declined in size or became extinct in different parts of the province

In North Tyrol, $A$. torrentium still is highly endangered due to its isolated populations. Continuous natural and anthropogenic impacts, from floods, river engineering and hydropower have threatened $A$. torrentium, especially the populations in Archbach in the Lech catchment A recent species action plan considers potential new habitats in the same catchment for the introduction of the stone crayfish.

As the indigenous crayfish species are endangered through different causes in different areas, species protection measures were proposed for several areas in the Austrian and Italian Tyrol (Table I). Due to the small size and the fragmented status of the populations, individual protection measures were applied. However in all cases, well designed and implemented measures are essential to ensure the survival of populations of the threatened crayfish species, taking account both the physical conditions and human factors. The measures proposed and partly implemented up to now (see Table I) will help to ensure the survival of freshwater crayfish in these areas, provided the measures are continued and completed.

The cost of proposed measures to improve habitat for crayfish represent only a small fraction of the overall costs of major projects affecting watercourses for purposes such as flood defence or other engineered works, but the conservation measures for crayfish were not usually taken into account. River engineers, environmental protection officers and scientists have started to work together for the sustainable development of indigenous crayfish populations in the Austrian and Italian Tyrol. These activities need to be continued at all levels and be coordinated better within an overall conservation strategy for indigenous crayfish in the whole region. Continuous awareness-raising and provision of information to the public are needed, together with full implementation of the proposed actions within the designated areas.

In the United Kingdom there has been a national conservation strategy (UK Biodiversity Action Plan) for $A$. pallipes and the introduction of regulations, but the preparation and implementation of conservation action plans in local areas has been more ad hoc. Nonetheless, as in the Tyrol, provisions for crayfish during engineering works on rivers is starting to occur in England too (Peay, 2003; Holdich et al., 2006). There is growing interest in setting up ark sites and work is starting on catchment scale action plans, although there are few examples yet e.g. the South-West crayfish conservation strategy and one for the Eden catchment in north-west England. 


\section{Table I}

Framework of crayfish species protection plans in North Tyrol (Austria) and South Tyrol (Italy): Protection measures, aims and implementation (ICS indigenous crayfish species, NICS non-indigenous crayfish species; AUT A. torrentium; AUP A. pallipes; ASA A. astacus; ASL A. leptodactylus; PCL P. leniusculus; OSL O. limosus).

\section{Tableau ।}

Cadre de protection des espèces d'écrevisses dans le nord du Tyrol (Autriche) et le sud du Tyrol (Italie) : les mesures de protection, les objectifs et leur mise en œuvre (ICS espèces d'écrevisses indigènes, NICS espèces d'écrevisses non-indigènes; AUT A. torrentium; PUA A. pallipes; ASA A. astacus ; ASL A. leptodactylus; PCL P. leniusculus; OSL O. limosus).

\begin{tabular}{|c|c|c|c|}
\hline $\begin{array}{l}\text { Protection } \\
\text { measure(s) }\end{array}$ & Aim(s) & $\begin{array}{l}\text { A. torrentium - Implemen- } \\
\text { tation North Tyrol }\end{array}$ & $\begin{array}{l}\text { A. pallipes - Implemen- } \\
\text { tation South Tyrol }\end{array}$ \\
\hline $\begin{array}{l}\text { Distribution } \\
\text { studies }\end{array}$ & $\begin{array}{l}\text { Up-to-date information } \\
\text { on ICS and NICS }\end{array}$ & $\begin{array}{l}\text { Carried out from } 1994 \\
\text { (Danube catchment - ICS: } \\
\text { ASA, AUT; NICS: PCL, } \\
\text { AUP) }\end{array}$ & $\begin{array}{l}\text { Carried out from } 1994 \\
\text { (Mediterranean catch- } \\
\text { ment - ICS: AUP; NICS: } \\
\text { ASA, OSL, PCL) }\end{array}$ \\
\hline $\begin{array}{l}\text { Identification of } \\
\text { threats }\end{array}$ & $\begin{array}{l}\text { Gain knowledge about } \\
\text { threats }\end{array}$ & $\begin{array}{l}\text { Habitat assessments at } \\
\text { reach, river and catchment } \\
\text { scales (e.g. Füreder and } \\
\text { Hanel, 2000) }\end{array}$ & $\begin{array}{l}\text { Habitat assessments } \\
\text { at reach, river and } \\
\text { catchment scales (e.g. } \\
\text { Füreder et al., 2002, } \\
\text { 2003) }\end{array}$ \\
\hline $\begin{array}{l}\text { Extension of } \\
\text { existing crayfish } \\
\text { habitats }\end{array}$ & $\begin{array}{l}\text { Restore crayfish habi- } \\
\text { tat, selectively remove } \\
\text { barriers to aid expan- } \\
\text { sion of range }\end{array}$ & $\begin{array}{l}\text { River widening, side chan- } \\
\text { nel construction in } 2009 \\
\text { and } 2010\end{array}$ & $\begin{array}{l}\text { Several projects pro- } \\
\text { posed and discussed, } \\
\text { but waiting to be imple- } \\
\text { mented }\end{array}$ \\
\hline $\begin{array}{l}\text { Restoration } \\
\text { of polluted, } \\
\text { or degraded } \\
\text { habitats, with } \\
\text { relict crayfish } \\
\text { population }\end{array}$ & $\begin{array}{l}\text { Remove or attenuate } \\
\text { human impacts to en- } \\
\text { able the recovery of } \\
\text { weakened populations }\end{array}$ & $\begin{array}{l}\text { Habitat demands of AUT } \\
\text { were taken into account in } \\
\text { flood protection measures } \\
\text { (e.g. Archbach) }\end{array}$ & $\begin{array}{l}\text { Several projects were } \\
\text { proposed and dis- } \\
\text { cussed, but not imple- } \\
\text { mented yet. }\end{array}$ \\
\hline $\begin{array}{l}\text { (Re)Introductions, } \\
\text { foundation of } \\
\text { new crayfish } \\
\text { populations (ark } \\
\text { sites) }\end{array}$ & $\begin{array}{l}\text { Reintroduce crayfish } \\
\text { populations } \quad \text { where } \\
\text { lost, start new crayfish } \\
\text { populations at suitable } \\
\text { locations }\end{array}$ & $\begin{array}{l}\text { Pilot studies in } 2004 \text { and } \\
2006 \text { with captive-bred } \\
\text { stock. } 2010 \text { new project } \\
\text { (ongoing activities in Arch- } \\
\text { bach and Vils Rivers) }\end{array}$ & $\begin{array}{l}\text { Pilot studies in 2001, } \\
2002,2003 \\
\text { Activities continued by } \\
\text { the fishery authorities }\end{array}$ \\
\hline $\begin{array}{l}\text { Creation of } \\
\text { regional gene } \\
\text { pools }\end{array}$ & $\begin{array}{l}\text { Genetic diversity and } \\
\text { uniqueness shall be } \\
\text { explored and obtained } \\
\text { by defining and/or } \\
\text { creating isolated gene } \\
\text { pool habitats }\end{array}$ & $\begin{array}{l}\text { Morphological and geno- } \\
\text { typical characterisation of } \\
\text { populations studied (Sint } \\
\text { et al., 2006, 2007; Füreder } \\
\text { et al., 2009b) }\end{array}$ & $\begin{array}{l}\text { Morphological and } \\
\text { genotypical character- } \\
\text { isation of populations } \\
\text { studied (Baric et al., } \\
\text { 2005a, 2005b; Füreder } \\
\text { et al., 2009b) }\end{array}$ \\
\hline Monitoring & $\begin{array}{l}\text { Monitoring of the de- } \\
\text { velopment of crayfish } \\
\text { populations and the } \\
\text { success of habitat } \\
\text { improvements and } \\
\text { (re)introductions }\end{array}$ & $\begin{array}{l}\text { No specific funding, how- } \\
\text { ever ongoing within running } \\
\text { projects }\end{array}$ & $\begin{array}{l}\text { No specific funding, } \\
\text { activities planned for } \\
2012\end{array}$ \\
\hline $\begin{array}{l}\text { Public relations; } \\
\text { outreach activi- } \\
\text { ties }\end{array}$ & $\begin{array}{l}\text { Building of public } \\
\text { awareness, various } \\
\text { information on crayfish } \\
\text { distribution, value and } \\
\text { threats }\end{array}$ & $\begin{array}{l}\text { Presentations at various } \\
\text { events, books (Füreder, } \\
\text { 2009), crayfish confer- } \\
\text { ences, newspaper articles, } \\
\text { TV, Radio }\end{array}$ & $\begin{array}{l}\text { Presentations at var- } \\
\text { ious events, book } \\
\text { (Füreder, 2009), folders, } \\
\text { crayfish conferences, } \\
\text { newspaper articles, TV, } \\
\text { Radio }\end{array}$ \\
\hline
\end{tabular}


Table I

Continued.

Tableau

Suite.

\begin{tabular}{|l|l|l|l|}
\hline $\begin{array}{l}\text { Protection } \\
\text { measure(s) }\end{array}$ & Aim(s) & $\begin{array}{l}\text { A. torrentium - Implemen- } \\
\text { tation North Tyrol }\end{array}$ & $\begin{array}{l}\text { A. pallipes - Implemen- } \\
\text { tation South Tyrol }\end{array}$ \\
\hline $\begin{array}{l}\text { Involvement } \\
\text { of water } \\
\text { managers, } \\
\begin{array}{l}\text { conservation } \\
\text { authorities, } \\
\text { fisheries, etc. }\end{array}\end{array}$ & $\begin{array}{l}\text { In relevant projects, } \\
\text { crayfish aspect should } \\
\text { be considered already } \\
\text { in the planning and } \\
\text { implementation phase }\end{array}$ & $\begin{array}{l}\text { Several examples (e.g. } \\
\text { Archbach and Vils River } \\
\text { flood protection engineer- } \\
\text { ing) }\end{array}$ & $\begin{array}{l}\text { Several examples } \text { (e.g. } \\
\text { water management and } \\
\text { irrigation plans at Kre- } \\
\text { busbach and Angel- } \\
\text { bach) }\end{array}$ \\
\hline
\end{tabular}

Table II shows examples of recent action for crayfish conservation in two river catchments in northern England. In both of those catchments there is progressive invasion by non-native crayfish underway and the emphasis in action for conservation is to find and protect safe, isolated ark sites for $A$. pallipes and minimize the risk of further human-assisted spread of $P$. leniusculus. In the Ribble catchment there has been some well-coordinated action since the arrival of crayfish plague, albeit without a formal conservation action plan. Despite major losses, measures have been put in place that will give good prospects for the survival of $A$. pallipes, but only in very limited areas compared to its former range in the catchment. In the Wharfe catchment, there have been some useful studies on the invasion by the NICS, but positive action for conservation has been slow to start. The process of conservation action planning at catchment scale is just getting started and is not yet well-coordinated. Progress is needed urgently if populations are to survive in at least some sub-catchments and sites. A lack of information about the status of crayfish in the tributaries and delays in securing landowner approval for conservation action are ongoing constraints, although the local rivers trust is seeking funding for a project that would involve volunteers in surveys of crayfish distribution and the search for potential ark sites. The main strategic aims are to find more existing or new ark sites for $A$. pallipes, before there are further losses of populations in the tributaries from invading $P$. leniusculus; maintain bio-security for current and future ark site populations, and minimize the risk to ark sites and other waterbodies in this and adjacent catchments by discouraging people from moving $P$. leniusculus around.

\section{> PROMOTE AWARENESS OF CRAYFISH AND INVOLVEMENT IN CONSERVATION ACTION}

Our ecological resources usually occur in catchments in which multiple land uses, and interactions among those uses, are likely to be present. Therefore action has to be defined and implemented to promote awareness of crayfish and the need for conservation measures. Sustainable situations for indigenous crayfish have to be supported by a real recognition of the problems and by the positive and responsible reaction by the public. Here we suggest the development of a strategic public relations plan by considering the following questions:

- Identification of target groups/stakeholders and goals: according to the species action plans, who are the ICS's key target stakeholders? Why is this target group/stakeholder important? What views in this target group/stakeholder would most aid or inhibit the action plan?

- Research on stakeholder(s): what is this stakeholder's current view of the ICS? What issues and appeals are important to this stakeholder? Which media does this stakeholder use and trust the most?

- Assessment and plan development: how does this target group/stakeholder's current view of the ICS differ from the desired one? What message themes will have the greatest impact on this target group/stakeholder? What are the best ways of reaching this target 
Table II

Issues for conservation of white-clawed crayfish Austropotamobius pallipes and action taken and planned in two catchments in Yorkshire, England, UK.

Tableau II

Problèmes de conservation des écrevisses à pattes blanches Austropotamobius pallipes et mesures prises et prévues dans deux bassins versants dans le Yorkshire, Angleterre, UK.

\begin{tabular}{|c|c|c|}
\hline Issue & Ribble catchment: action & Wharfe catchment: action \\
\hline $\begin{array}{l}\text { Crayfish status } \\
2010\end{array}$ & $\begin{array}{l}\text { Outbreak of crayfish plague } 2002 \text {, } \\
\text { fish-stocking. Only } 3 \text { relict popula- } \\
\text { tions left, } 1 \text { population being out- } \\
\text { competed by } P \text {. leniusculus, almost } \\
\text { gone by } 2010\end{array}$ & $\begin{array}{l}\text { Progressive replacement } A \text {. pallipes by } \\
P \text {. leniusculus in upper catchment. } \\
A . \text { pallipes relict populations in some } \\
\text { tributaries, current status uncertain. }\end{array}$ \\
\hline $\begin{array}{l}\text { Ark sites (exist- } \\
\text { ing or new 'safe' } \\
\text { areas for } A \text {. pal- } \\
\text { lipes, isolated } \\
\text { from invasion by } \\
\text { non-indigenous } \\
\text { crayfish or cray- } \\
\text { fish plague) }\end{array}$ & $\begin{array}{l}\text { One stillwater ark site. Semi-isolated } \\
\text { A.pallipes in headwater tributary } \\
\text { given new barrier } 2009 \text { (Bradley, } \\
\text { 2010). } \\
\text { Tributary re-stocked 2007, a future } \\
\text { wild stock for ark sites. New ark site } \\
\text { started with wild stock upstream wa- } \\
\text { terfall, } 2008 \text { (Peay and Guthrie, 2008). }\end{array}$ & $\begin{array}{l}\text { New ark site in quarry } 2010 \text { with local } \\
\text { wild stock. } \\
\text { Possible existing ark site upstream } \\
\text { of reservoirs, status uncertain. Needs } \\
\text { survey. } \\
\text { Water company ban on reservoirs as } \\
\text { new ark sites, pending review of con- } \\
\text { straints/ costs. Action } 2011 \text { aim for } \\
\text { agreement on } A \text {. pallipes sites with wa- } \\
\text { ter co. and regulators, for potential fu- } \\
\text { ture ark sites }\end{array}$ \\
\hline Monitoring & Ongoing monitoring all populations. & $\begin{array}{l}P \text {. leniusculus in main river tracked } \\
1990 \text { to } 2008 \text { (Peay and Rogers, 1999; } \\
\text { Bubb et al., 2005; Imhoff, 2010). Sur- } \\
\text { veys for remaining A. pallipes in tribu- } \\
\text { taries planned 2011-2012 with volun- } \\
\text { teers. } \\
\text { Experimental test of } A \text {. pallipes in small } \\
\text { ponds in 2008, periodic monitoring in } \\
\text { progress }\end{array}$ \\
\hline $\begin{array}{l}\text { Fisheries } \\
\text { management }\end{array}$ & $\begin{array}{l}\text { Switched to wild fishery from } 2003 \text {, } \\
\text { except if re-stocking after pollution or } \\
\text { similar. Ongoing habitat improvement } \\
\text { for salmonid fish. Local concern re } \\
\text { impact } P \text {. leniusculus on trout recruit- } \\
\text { ment (Peay et al., 2009) }\end{array}$ & $\begin{array}{l}\text { No coordinated fisheries management, } \\
\text { many angling clubs, stocking from } \\
\text { different suppliers one 'put-and-take' } \\
\text { fishery two trout farms }\end{array}$ \\
\hline $\begin{array}{l}\text { Harvest/control } \\
\text { of non-native } \\
\text { crayfish }\end{array}$ & $\begin{array}{l}\text { No wild harvest of } P \text {. leniusculus per- } \\
\text { mitted. }\end{array}$ & $\begin{array}{l}\text { No wild harvest } P \text {. leniusculus permit- } \\
\text { ted. One angling club trapped for con- } \\
\text { trol, gave up as ineffective. Some (ille- } \\
\text { gal) taking of } P \text {. leniusculus at popular } \\
\text { riverside 'beach', a risk due to ark site } \\
\text { in nearby city. }\end{array}$ \\
\hline $\begin{array}{l}\text { Eradication of } \\
\text { non-native } \\
\text { crayfish }\end{array}$ & $\begin{array}{l}\text { Biocide treatment of stream with } P \text {. le- } \\
\text { niusculus authorized for } 2007-2008 \text {, } \\
\text { NICS got to larger stream, no treat- } \\
\text { ment done. }\end{array}$ & $\begin{array}{l}\text { None possible; river too large, popula- } \\
\text { tion too extensive. }\end{array}$ \\
\hline $\begin{array}{l}\text { Education and } \\
\text { promotion }\end{array}$ & $\begin{array}{l}\text { Environment Agency and Rivers } \\
\text { Trusts awareness-raising with angling } \\
\text { clubs. Local people kept informed } \\
\text { Good media coverage. } \\
\text { Successful captive-breeding A. pal- } \\
\text { lipes from 2003, provides stock for } \\
\text { public exhibitions. }\end{array}$ & $\begin{array}{l}\text { Upper catchment in National Park. } \\
\text { Some public awareness raising, but } \\
\text { needs more, especially to discourage } \\
\text { wild harvest } P \text {. leniusculus. } \\
\text { Local naturalists group and other vol- } \\
\text { unteers would help in surveys/action, } \\
\text { seek potential ark sites; needs funding } \\
\text { for local coordination }\end{array}$ \\
\hline
\end{tabular}


group/stakeholder? Who will serve as the primary contact for working with this target group/stakeholder?

- Selecting and setting objectives: what short-term objectives will lead to the goals of the action plan?

- Actions needed to reach these objectives: what specific actions or messages will lead to achieving this objective? What resources will be needed for these tasks?

- Identify specific people, equipment, and funds needed: when should it be done? How will success in achieving each objective be evaluated?

An example of putting a message across to a target audience was a campaign run by the South West Crayfish Conservation group in England in 2010. Because of the local problem of transmission of crayfish plague, the group produced a leaflet "angling and crayfish essentials" to distribute to anglers. The leaflet was on water-resistant paper folded to the size of a credit card and well illustrated to attract interest, with an angler on the front page. It provided some useful websites and telephone numbers of general interest to anglers. It gave brief notes on the threats to white-clawed crayfish, local conservation action, the impacts of signal crayfish and on the law regarding crayfish. It finished with a crayfish code with three "don'ts" on a red background and three "dos" on a green one:

- do not introduce crayfish to the wild;

- do not trap or remove crayfish (without a trapping licence);

- never use crayfish as bait;

- disinfect or wash and dry equipment and footwear;

- protect native crayfish habitat;

- report sightings to the Environment Agency.

The leaflet was distributed to local angling clubs, in angling shops and angling events and stimulated local interest. Questionnaire surveys were carried out before and in the year after the distribution of the leaflets at a popular angling club and showed that there was a significant increase in awareness about crayfish conservation and crayfish plague and greater willingness to disinfect angling gear (Rees, to appear). Significant increases in general public awareness were also recorded due to a public display at Bristol Zoo, showing the success of a well-implemented public awareness campaign

Actions by regulators on their own are unlikely to be sufficient to conserve ICS. In our view, it is important to make a wide range of stakeholders, including the general public, aware of ICS, aware of the threats to them and to believe that keeping indigenous crayfish matters and can be achieved.

\section{DISCUSSION}

The primary reasons for loss of biodiversity are demographic, economic, and institutional factors, including increasing demands for land and biological resources due to the growth in the human population, world production, consumption and trade. These factors are associated with a failure of people and markets to take into account the long-term consequences of environmental changes and the full array of biodiversity values.

The situations of the freshwater crayfish species $A$. pallipes and $A$. torrentium provide dramatic examples of some of these causes in action. The loss, fragmentation, and degradation of habitats; the overexploitation of biological resources; the introduction of non-native species; and the pollution of water have caused major decreases in the extent of these indigenous crayfish species ( $A$. pallipes in England, both species in the Austrian and Italian Tyrol). These factors are operating not only in the cases described here, but also in most other parts of the European ranges of the two species and adversely affect other species in freshwater habitats too. The loss of species and genetic variability is essentially irreversible, and therefore poses serious threats to sustainable development and the quality of life of future generations. 
On the other hand, the implementation of the protection programs on freshwater crayfish in the Austrian and Italian Tyrol potentially has good prospects, as does the increasing interest in conservation of $A$. pallipes in England in recent years. All too often, biodiversity has been disregarded in favour of economic or other human interests. There may have been insufficient awareness and recognition among decision makers and the general public about the importance of species diversity and habitat quality on the multiple ecosystem services on which humankind depends, but there are signs that this is beginning to change. Freshwater crayfish have been known and appreciated in the Austrian and Italian Tyrol from before the Medieval period and were also valued in England, with $A$. pallipes being extended beyond its natural range into north and west England. The high cultural value of indigenous crayfish had been largely forgotten by the 20th century in the Austrian and Italian Tyrol and in England, but it should be re-considered now.

Policy-makers and decisionmakers and the public need to understand that environmental management (e.g., river engineering for flood protection) should take into account biological deficiencies at regional and international level, rather than just short-term economic or social needs. The decrease of species and decline of intact and functioning ecosystems is not only the interest of a specific region, community or family, but is a global problem. There has been a recent shift in awareness and a growing willingness within society to understand and attempt to minimize environmental impact, but the valuation of biodiversity and ecosystem services still is in debate. Most ICS in Europe occur within ecosystems that are degraded or used unsustainably.

It is easier to engage public interest in attractive mammals or birds, but more difficult to encourage interest in invertebrates, which are often ignored, or may even be viewed with some antipathy unless they are conspicuously attractive species, such as some butterfly species. Yet indigenous crayfish species are large enough animals to spark the curiosity of children and adults alike. This has been the experience of the authors when we have given people the opportunity to see or handle crayfish. At the same time, ICS are keystone species in aquatic ecosystems and under threat. Using ICS as case studies may help to broaden and deepen understanding of the importance of biodiversity and ecosystem services and how they are affected by human action.

We re-iterate the recommendations for stakeholders at European, national and regional scales to: (1) put regulation in place; (2) plan and coordinate action; (3) assess risk at catchment scale; (4) prepare and implement conservation action plans; (5) involve people with the conservation of crayfish. Despite the threats to ICS, we think this is a case where interest and conservation action at local, regional and national scale can make a positive difference and offer the hope of keeping these quietly charismatic species.

\section{REFERENCES}

Alonso F., Temino C. and Diéguez-Uribeondo J., 2000. Status of the white-clawed crayfish, Austropotamobius pallipes (Lereboullet, 1858), in Spain: distribution and legislation. Bull. Fr. Pêche Piscic., 356, 31-53.

Baric S., Höllrigl A., Füreder L. and Dalla Via J., 2005a. Mitochondrial and microsatellite analyses of Austropotamobius pallipes populations in South Tyrol (Italy) and Tyrol (Austria). Bull. Fr. Pêche Piscic., 376-377, 599-612.

Baric S., Höllrigl A., Kerschbamer C., Füreder L., Petutschnig J., Dalla Via J., 2005b. Update of the molecular phylogeny of the Austropotamobius pallipes species complex by including specimens from South Tyrol (Italy) and Carinthia (Austria). Bull. Fr. Pêche Piscic., 376-377, 627-636.

Bradley P., 2010. Ribblesdale Crayfish Conservation Project, December 2010. Environment Agency, North-west, Preston, UK.

Bubb D.H., Thom T. J. and Lucas M. C. 2005. The within-catchment invasion of the non-indigenous signal crayfish Pacifastacus leniusculus (Dana) in upland rivers. Bull. Fr. Pêche Piscic., 376-377, 665-673.

Christmas M., 2009. England Biodiversity Strategy 2010 to 2015 Atlantic Stream or White-Clawed Crayfish - Austropotamobius pallipes, Environment Agency, Leeds, UK. In: Peay S., Kindemba 
V., Attwood F. and Christmas M. (eds.), 2011. A toolkit for developing catchment-scale conservation strategy for White-clawed crayfish, Version 1, October 2011, Buglife - The Invertebrate Conservation Trust, Peterborough, 48-50.

Edsman L., 2004. The Swedish story about import of live crayfish. Bull. Fr. Pêche Piscic., 372-373, 281-288.

Edsman L. and Smietana P., 2004. Roundtable session 2: Exploitation, conservation and legislation. Bull. Fr. Pêche Piscic., 372-373, 457-464.

Environment Agency, 2010. Unpublished data from Fisheries licensing database, National Fisheries Laboratory, Brampton, England.

Foster J. and Turner C., 1993. Toxicity and field simulated farm waste episodes to the crayfish Austropotamobius pallipes (Lereboullet): elevated ammonia and reduced dissolved oxygen concentrations. Freshwater Crayfish, 9, 249-258.

Füreder L., 2009. Flusskrebse, Biologie - Ökologie - Gefährdung, Veröffentlichungen des Naturmuseums Südtirol, 6, Folio Verlag, Wien-Bozen, 144 p.

Füreder L. and Hanel R., 2000. Flusskrebse in Gewässern Nord- und Osttirols: Verbreitung, ökologische Bedeutung und Schutzmaßnahmen. Ber. Nat.-Med. Verein Innsbruck, 87, 221-241.

Füreder L. and Pöckl M., 2007. Ecological traits of aquatic NIS invading Austrian fresh waters. In: Gherardi F. (ed.), Biological invaders in inland waters: profiles, distribution and Threats, Springer, Dordrecht, 233-257.

Füreder L., Oberkofler B., Hanel R. and Machino Y., 2002. Freshwater crayfish in South Tyrol (Italy): distribution and protection measures of endangered Austropotamobius pallipes. Bull. Fr. Pêche Piscic., 367, 651-662.

Füreder L., Oberkofler B., Hanel R., Leiter J. and Thaler B., 2003. The freshwater crayfish Austropotamobius pallipes in South Tyrol: heritage species and bioindicator Bull. Fr. Pêche Piscic., 370-371, 81-95.

Füreder L., Edsman L., Holdich D.M., Kozák P., Machino Y., Pöckl M., Renai B., Reynolds J., Schulz H., Sint D., Taugbøl T. and Trouilhé M.C., 2006. Indigenous crayfish habitat and threats. In: SoutyGrosset C., Holdich D. M., Noël P.Y., Reynolds J.D. and Haffner P. (eds.), Atlas of Crayfish in Europe Patrimoines naturels, 64, Muséum national d'Histoire naturelle, Paris, France, 25-48.

Füreder L., Weinländer M. and Perlinger H., 2009a. Die Flusskrebse Österreichs. In: Füreder L. (ed.), Flusskrebse, Biologie - Ökologie - Gefährdung, Veröffentlichungen des Naturmuseums Südtirol, 6, Folio Verlag, Wien-Bozen, 82-91.

Füreder L., Summerer M. and Brandstätter A., 2009b. Phylogeny and species composition of five European species of Branchiobdella (Annelida: Clitellata: Branchiobdellida) reflect the biogeographic history of three endangered crayfish species. J. Zool., 279, 164-172.

Füreder L., Gherardi F., Holdich D., Reynolds J., Sibley P. and Souty-Grosset C., $2010 a$. Austropotamobius pallipes. In: IUCN 2010, IUCN Red List of Threatened Species, Version 2010.4, www.iucnredlist.org (accessed 7th January 2011).

Füreder L., Gherardi F. and Souty-Grosset C., 2010b. Austropotamobius torrentium. In: IUCN 2010, IUCN Red List of Threatened Species, Version 2010.4, www.iucnredlist.org (accessed 7th January 2011).

García-Arberas L., Rallo A. and Antón A., 2010. The future of the indigenous freshwater crayfish Austropotamobius italicus in Basque Country streams: Is it possible to survive being an inconvenient species? Knowl. Managt. Aquatic Ecosyst., 394-395, 19.

Gherardi F., 2007. Understanding the impact of invasive crayfish. In: Gherardi F. (ed.), Biological invaders in inland waters: profiles, distribution and threats, Springer, Dordrecht, 507-542.

Grandjean F., Gouin N., Keith P. Noël P. Persat H., Reynolds J., Schulz H., Smietana P. and SoutyGrosset C., 2006. In: Souty-Grosset C., Holdich D. M., Noël P. Y., Reynolds J. D. and Haffner P. (eds.), Atlas of Crayfish in Europe. Patrimoines naturels, 64, Muséum national d'Histoire naturelle, Paris, France, 12-23.

Hansard, 2011. Environment, Food and Rural Affairs Written Response 8th February 2011, crayfish, House of Commons Written Answers, 523, Part 114, http://services.parliament.uk/hansard/ Commons/bydate/20110208/writtenanswers/part005.html (accessed 15th February 2011).

Hefti D. and Stucki P., 2006. Crayfish management for Swiss waters. Bull. Fr. Pêche Piscic., 380-381, 937-950.

Holdich D.M., 1999. The negative effects of established crayfish introductions. In: Gherardi F. and Holdich D.M. (eds.), Crayfish in Europe as alien species - how to make the best of a bad situation?, A.A. Balkema, Rotterdam, 31-47. 
Holdich D.M., 2002. Distribution of crayfish in Europe and some adjoining countries. Bull. Fr. Pêche Piscic., 367, 611-650.

Holdich D.M. and Pöckl M., 2005. Does legislation work in protecting vulnerable species? Bull. Fr. Pêche Piscic., 376-377, 809-827.

Holdich D.M. and Pöckl M., 2007. Invasive crustaceans in European inland waters. In: Gherardi F. (ed.), Biological invaders in inland waters: profiles, distribution and threats, Springer, Dordrecht, 29-75.

Holdich D.M., Peay S., Foster J., Hiley P.D. and Brickland J.H., 2006. White-clawed crayfish associated with muddy habitats. Bull. Fr. Pêche Piscic., 380-381, 1055-1078.

Holdich D.M., Reynolds J.D., Souty-Grosset C. and Sibley P.J., 2009., A review of the ever increasing threat to European crayfish from non-indigenous crayfish species. Knowl. Managt. Aquatic Ecosyst., 394-395, 11.

Howells M. and Slater F., 2004. Remnant populations of Austropotamobius pallipes in Wales, UK: counts, causes, cures and consequences. Freshwater Crayfish 14, 140-146.

Imhoff E.M., 2010. The impact of water chemistry and parasitism by Thelohania contejeani (Microspora) on native (Austropotamobius pallipes) and invasive (Pacifastacus leniusculus) crayfish and their interactions, Ph.D. Theisis, The University of Leeds Faculty of Biological Sciences, Leeds.

Kemp E., Birkinshaw N., Peay S. and Hiley P.D., 2003. Re-introducing the white-clawed crayfish Austropotamobius pallipes, Conserving Natura 2000 Rivers Conservation Techniques Series No. 1. English Nature, Peterborough, http://www.english-nature.org.uk/lifeinukrivers/species/crayfish_ reintroduction.pdf (accessed April 7th 2011).

Lerat D., Paris L. and Baran P., 2006. Statut de l'écrevisse a pattes blanches (Austropotamobius pallipes Lereboullet, 1858) en Bourgogne, bilan de 5 années de prospection. Bull. Fr. Pêche Piscic., 380381, 867-882.

Lyons R. and Kelly-Quinn M., 2003. An investigation into the disappearance of Austropotamobius pallipes (Lereboullet) populations in the headwaters of the Nore river, Ireland and the correlation to water quality. Bull. Fr. Pêche Piscic., 370-371, 139-151.

Maguire I., 2009. Die Flusskrebse Osteuropas. In: Füreder L. (ed.), Flusskrebse, Biologie - Ökologie Gefährdung, Veröffentlichungen des Naturmuseums Südtirol, 6, Folio Verlag, Wien-Bozen, 92-97.

Martinéz R., Rico E. and Alonso F., 2003. Characterisation of Austropotamobius italicus (Faxon, 1914) populations in a central Spain area. Bull. Fr. Pêche Piscic., 370-371, 43-56.

Millennium Ecosystem Assessment, 2005. Ecosystems and Human Well-being: Biodiversity Synthesis, World Resources Institute, Washington, DC.

Nightingale J., 2009. Conservation of white-clawed crayfish in South-west England. In: Brickland J., Holdich D.M. and Imhoff E.M. (eds.), Crayfish Conservation in the British Isles, Proceedings of conference held on 25th March 2009, Leeds, UK, 85-86.

Peay S., 2003. Minimising loss of crayfish and habitat during works on watercourses. Bull. Fr. Pêche Piscic., 370-371, 193-207.

Peay S., 2009a. Invasive non-indigenous crayfish species in Europe: recommendations on managing them. Knowl. Managt. Aquatic Ecosyst., 394-395, 03.

Peay S., 2009b. Selection Criteria for "ark sites" for white-clawed crayfish. In: Brickland J., Holdich D.M. and Imhoff E.M. (ed.), Crayfish Conservation in the British Isles, Proceedings of conference held on 25th March 2009, Leeds, UK, 63-70.

Peay S. and Guthrie N., 2008. A safe refuge for white-clawed crayfish in a stream in North Yorkshire? Crayfish News, 30, 5-7.

Peay S. and Rogers D., 1999. The peristaltic spread of signal crayfish (Pacifastacus leniusculus) in the River Wharfe, Yorkshire, England. Freshwater Crayfish, 12, 665-676.

Peay S., Guthrie N., Spees J., Nilsson E. and Bradley P., 2009. The impact of signal crayfish (Pacifastacus leniusculus) on the recruitment of salmonid fish in a headwater stream in Yorkshire, England. Knowl. Managt. Aquatic Ecosyst., 394-395, 12.

Peay S. Holdich D.M. and Brickland J., 2010. Risk assessments of non-indigenous crayfish in Great Britain. Freshwater Crayfish, 17, 109-122.

Peay S., Kindemba V., Attwood F. and Christmas M., 2011. A toolkit for developing catchment-scale conservation strategy for White-clawed crayfish, Version 1, October 2011, Buglife - The Invertebrate Conservation Trust, Peterborough.

Puky M. and Schád P., 2006. Orconectes limosus colonises new areas fast along the Danube in Hungary. Bull. Fr. Pêche Piscic., 380-381, 919-926. 
Rees M., to appear. Evaluation of the South West Crayfish Project (SWCP) communication strategy 2009 to 2010. In: Rees M., Nightingale J. and Holdich D. (eds.), Species Survival: Securing whiteclawed crayfish in a changing environment, Proceedings of a conference held on the 16th and 17th November 2010 in Bristol, UK.

Renai B., Bertocchi S., Brusconi S., Grandjean F., Lebboroni M., Parinet B., Souty-Grosset C., Trouilhé M.C. and Gherardi F., 2006. Ecological characterisation of streams in Tuscany (Italy) for the management of the threatened crayfish Austropotamobius pallipes complex. Bull. Fr. Pêche Piscic., 380-381, 1095-1114.

Reynolds J.D., 2009. The current status of white-clawed crayfish in Ireland. In: Brickland J., Holdich D.M. and Imhoff E.M. (ed.), Crayfish Conservation in the British Isles, Proceedings of conference held on 25th March 2009, Leeds, UK, 35-41.

Reynolds J.D. 2011. A review of ecological interactions between crayfish and fish, indigenous and introduced. Knowl. Managt. Aquatic Ecosyst., 401, 10.

Reynolds J.D., Demers A., Peay S., Puky M., Sibley P., Souty-Grosset C. and Taugbøl T., 2006. Crayfish conservation and management. In: Souty-Grosset C., Holdich D.M., Noël P.Y., Reynolds J.D. and Haffner P. (eds.), Atlas of crayfish in Europe, Patrimoines naturels, 64, Muséum national d'Histoire naturelle, Paris, 152-157.

Schubart C.D. and Huber M.G.J., 2006. Genetic comparisons of German populations of the stone crayfish, Austropotamobius torrentium (Crustacea: Astacidae). Bull. Fr. Pêche Piscic., 380-381, 10191028.

Schulz H.K., Smietana P. and Schulz R., 2002. Crayfish occurrence in relation to land-use properties: implementation of a Geographic Information System. Bull. Fr. Pêche Piscic., 367, 861-874.

Sint D., Dalla Via J. and Füreder L., 2006. The genus Austropotamobius in the Ausserfern Region (Tyrol - Austria) with an overlap in the distribution of $A$. torrentium and $A$. pallipes populations. Bull. Fr. Pêche Piscic., 380-381, 1029-1040.

Sint D., Dalla Via J. and Füreder L., 2007. Phenotypical characterisation of indigenous freshwater crayfish populations. J. Zool., 273, 210-219.

Söderhäll K. and Cerenius L., 1999. The crayfish plague fungus:history and recent advances. Freshwater Crayfish, 12, 11-35.

Souty-Grosset C., Grandjean F. and Gouin N., 2004. Conservation and management of native crayfish populations. Freshwater Crayfish, 14, 1-20.

Souty-Grosset C., Holdich D.M., Noël P.Y., Reynolds J.D. and Haffner P., 2006. Atlas of Crayfish in Europe Muséum national d'Histoire naturelle, Paris, France, $187 \mathrm{p}$.

Thomas W. and Ingle R., 1971. The nomenclature, bionomics and distribution of the crayfish, Austropotambius pallipes (Lereboullet) (Crustacea, Astacidae) in the British Isles. Essex Naturalist, 32, 349-360.

Tricarico E., Vilizzi L, Gherardi F. and Copp GH., 2010. Calibration of FI-ISK, an invasiveness screening tool for nonnative freshwater invertebrates. Risk Anal., 30, 285-292.

Trouilhé M.C., Ricard F., Parinet B., Grandjean F. and Souty-Grosset C., 2003. Management of the whiteclawed crayfish (Austropotamobius pallipes) in western France: abiotic and biotic factors study. Bull. Fr. Pêche Piscic., 367, 97-114.

Trouilhé M.C., Souty-Grosset C., Grandjean F. and Parinet B., 2007. Physical and chemical water requirements of the whiteclawed crayfish (Austropotamobius pallipes) in western France. Aquat. Conserv., 17, 520-538.

UK Biodiversity Steering Group, 1995. Biodiversity: the UK Steering Group report: Volume II: Action plans (Tranche 1), HMSO, London, 57-58, http://www.ukbap.org.uk/UKPlans.aspx?ID=124 (accessed 11th January 2011).

Vigneux E., Thibault F., Marnell F. and Souty-Grosset C., 2002. National Legislation, EU directives and conservation. Bull. Fr. Pêche Piscic., 367, 887-898.

Weinländer M. and Füreder L., 2009. The continuing spread of Pacifastacus leniusculus in Carinthia (Austria). Knowl. Managt. Aquatic Ecosyst., 394-395, 17. 